\title{
Antioxidant Activities of Martynia annua Linn. Root Extract
}

\author{
Research Article
}

\section{Rahul Kumar Gupta $^{1^{*}}$, Meena Shamrao Deogade ${ }^{2}$}

1. PhD Scholar, 2. Professor, Department of Dravyaguna, Mahatma Gandhi Ayurved College Hospital and Research centre, Wardha, MS 442001

\begin{abstract}
Background: Antioxidants play a significant role to protect harm caused by oxidative stress (OS). Plants having phenolic substances are reported to possess antioxidant properties. The present study was intended to research the antioxidant potential of aqueous extract, Hydroalcoholic extract and Alcoholic extract from Martynia annua root. Martynia annua (cat's claw, bichu) belongs to Martyniaceae family. For centuries, extracts of leaves, roots, stems, roots and seeds of $M$. апnиa have been used to cure eplilepsy, inflammation, tuberculosis, skin infections etc. Methods: The antioxidant activities of Aqueous, Hydroalcoholic and Alcoholic extractives were evaluated by using DPPH free radical assay. DPPH (1,1-diphenyl-2-picrylhydrazyine) free radical analysis is one of the accurate and frequently employed method for evaluating antioxidant activity. Results: Aqueous, Hydroalcoholic and Alcoholic extracts of Martynia annua root were explored which revealed that with increase in concentration of extracts resulted in increased degree of reduction. The IC50 values were calculated for all three extracts. Ascorbic acid was used as control. Martynia annua exhibited IC50 of $69.58 \pm 3.44 \mu \mathrm{g} / \mathrm{ml}, 70.91 \pm 2.91 \mu \mathrm{g} / \mathrm{ml}$ \& $68.49 \pm 3.15 \mu \mathrm{g} / \mathrm{ml}$ for Hydro-alcoholic extract, aqueous extract \& ethanolic extract respectively while Ascorbic acid exhibited IC 50 of $62.91 \pm 2.85 \mu \mathrm{g} / \mathrm{ml}$. Conclusions: Scientific evidence suggests that antioxidants reduce the risk for chronic diseases including cancer and heart disease and infectious diseases. Further evaluation of pharmacological activities and cell line studies of Martynia annua may prove useful in treatment of cancer and heart diseases.
\end{abstract}

Keywords: Martynia annua, Antioxidant, DPPH assay

\section{Introdcution}

For thousands of years, plants have been a good source of medicine to treat ailment and maintain health. Mostly roots, flowers, leaves, root, stem, barks and seeds of plants are rich in secondary metabolites that produce definite pharmacological effects on human body.

M. апnиa is an upright short-lived herbaceous plant. The roots are white in colour with characteristic odour. M. annua belongs to family Martyniaceae and it is commonly found in dense cluster on roadsides, degraded moist and dry deciduous forest, waste lands and over-grazed pasture. It is a weedy foreign species native to tropical and sub-tropical region of Mexico, Central America, Burma, West Pakistan and naturalized throughout India. Its excellent dispersal mechanism has helped it spread throughout the tropical world as a weed.(1)

In folklore practices decoction of whole plant is given in pneumonia and cold fever. The poultice of roots used in snake bite for external application. Roots of Martynia annua are boiled in milk and taken as a tonic in folklore. In Tribal Pockets of Satpura Plateau in Madhya Pradesh, Root paste of Martynia annua is used

*Corresponding Author:

Rahul Kumar Gupta,

PhD Scholar,

Mahatma Gandhi Ayurved College Hospital and

Research centre, Wardha, MS 442001

Email: drrahulkgupta17@gmail.com to treat Cancer and rheumatism.(2) The juice of the leaves is used as a gargle for sore throat and the leaf paste for wounds of domestic animals.(3) The unripe fruits of M. annua found to have antioxidant activity(4) and the ash of fruits mixed with coconut oil are used to cure burns.(5) The roots are also used as local sedative and antidote to scorpion stings.(6) Seed oil is used for abscesses and treating itching and skin infections. The seeds of M.аnnua are used for prevention of graying of hair.(7)The whole plant is used for fever, hair loss, scabies and abscess on the back.(8)

An antioxidant is a substance that prevents or delays oxidation of other molecules. Free radicals are produced during oxidation which can be trapped by antioxidants. In plants, natural exogenic antioxidant substances are available i.e. flavonoids, phenolic diterpenes, oils, vitamins phenolic acids and plant pigments like anthocyanins scavenge free radicals such as hydro peroxide, peroxide or lipid peroxidation. Free radical and reactive oxygen species(ROS) are basically the main causes of several disorders in humans like cancer, heart disease, ageing, diabetes, Alzheimer's, Parkinson's diseases (9) by inhibiting a reaction cycle. Different methods are used to assess the antioxidant and free radical scavenging activity. In vitro antioxidant activity is mostly measured by DPPH method developed by Biols (1958), hydrogen peroxide scavenging assay, nitric acid scavenging activity, ferric reducing antioxidant power assay, and reducing power method. Present investigation reports DPPH, assay activities of the root extracts of M. апnиa. 


\section{Study protocol DPPH assay}

By using stable free radical, 1,1-diphenyl-2picrylhydrazyine, the odd electron of nitrogen in DPPH is reduced by receiving hydrogen from antioxidants to corresponding hydrazine.(10)

The present study revealed the in vitro antioxidant activities of ethanolic root extract partitioned in different solvents (ethanol, water and hydro ethanol) by scavenging effect on 1,1-diphenyl-2 -picryldrazyl, assay to protect the oxidative damage.

\section{Materials and Methods}

The plant was collected from Govt. Ayurved College Campus, Gwalior (Madhyapradesh). Preserved this plant as herbarium in departmental repository and was authenticated from Regional Ayurveda Research Institute for Metabolic Disorders (RARI) Bangalore (Karnataka). Its authentication number is Authentication/SMPU/RARIMD /BNG/2017-18, Bengaluru, Dated 26/02/2018.

\section{Antioxidant activity}

\section{2,2-diphenyl-1-picrylhydrazy (DPPH) Assay}

Procedure: DPPH (1, 1-diphenyl-2picrylhydrazyl (a, a-diphenyl-bpicrylhydrazyl) radical scavenging analysis was performed according to the reported method with slight modifications. Briefly, 1 $\mathrm{mg} / \mathrm{ml}$ solutions of compound(s) and ascorbic acid were prepared by dissolving them into DMSO (Dimethyl sulfoxide). 25, 50, 75 and $100 \mu \mathrm{L}$ of each was added separately to $10.0 \mathrm{~mL}$ amber color volumetric flasks containing $2.0 \mathrm{ml}$ of $0.01 \mathrm{mM}$ DPPH (prepared in ethanol). The final volume was made up to $3.0 \mathrm{ml}$ and allowed to stand for 30 minutes in the dark and after 30 min absorbance was checked at $517 \mathrm{~nm}$ by using UVvisible spectrophotometer. Pure DPPH solution $(0.01 \mathrm{mM})$ was used as a control and ethanol was as a blank. The decrease of in absorbance equates the DPPH radical scavenging capacity. The above process was repeated three times for ascorbic acid (positive control) and compounds/ sample(s).

The radical scavenging ability was calculated according to the formula:

Radical scavenging activity $=\left(\mathrm{A}_{0}-\mathrm{A}_{\mathrm{T} /} \mathrm{A}_{0}\right) \times 100$; where, $A_{0}$ is the absorbance of pure DPPH solution $(0.01 \mathrm{mM})$, and $A_{T}$ is the absorbance of $(\mathrm{DPPH})$ and compound(s)/ sample(s).

\section{Results and Discussion}

Several concentrations ranging from 25 to 100 $\mu \mathrm{g} / \mathrm{mL}$ of the $M$. аппиа root extract were tested for antioxidant activity in different in vitro models. $M$. annua root extract exhibited a comparable antioxidant activity with that of standard ascorbic acid at varying concentrations tested $(25,50,75$ and $10025 \mu \mathrm{L})$. There was a dose-dependent increase in the percentage antioxidant activity for all concentrations tested. Ascorbic acid was used as the standard drug for the assurance of the antioxidant activity by DPPH assay. The concentration of ascorbic acid varied from 1 to 60 $\mu \mathrm{g} / \mathrm{mL}$. Ascorbic acid at a concentration of $25 \mu \mathrm{L}$ exhibited a percentage inhibition of $32.87 \pm 1.35 \%$ and for $100 \mu \mathrm{L} 70.34 \pm 2.88 \%$ (Table 1 ). The $\mathrm{IC}_{50}$ value of ascorbic acid was $62.91 \pm 2.85$. $\mathrm{IC}_{50}$ value was observed $70.91 \pm 2.91$ for the aqueous extract, $69.58 \pm 3.44$ for Hydro-alcoholic extract and $68.49 \pm 3.15$ for Ethanolic extract. From Figure 1and Table 1, it is observed that all extracts show significant DPPH radical scavenging property and almost close activity to ascorbic acid (as shown in fig.1). Among all, Aqueous extract possessed highest antioxidant activity.

Table 1: Percentage inhibition of standard (ascorbic acid) and test drug

\begin{tabular}{|c|c|c|c|c|c|}
\hline \multirow{2}{*}{$\begin{array}{l}\text { Sample or } \\
\text { Extract }\end{array}$} & \multicolumn{4}{|c|}{$\begin{array}{l}\text { \% inhibition at different } \\
\text { concentrations }\end{array}$} & \multirow{2}{*}{$\begin{array}{l}\mathrm{IC}_{50} \\
(\boldsymbol{\mu g} / \\
\mathrm{ml})\end{array}$} \\
\hline & $25 \mu \mathrm{L}$ & $50 \mu \mathrm{L}$ & $75 \mu \mathrm{L}$ & $\begin{array}{l}100 \\
\mu \mathrm{L}\end{array}$ & \\
\hline $\begin{array}{l}\text { Hydro- } \\
\text { alcoholic }\end{array}$ & $\begin{array}{l}26.89 \pm \\
1.65\end{array}$ & $\begin{array}{l}38.62 \\
\pm 2.06\end{array}$ & $\begin{array}{l}53.10 \\
\pm 3.05\end{array}$ & $\begin{array}{r}66.43 \\
\pm 3.78\end{array}$ & $\begin{array}{l}69.58 \\
\pm 3.44\end{array}$ \\
\hline Aqueous & $\begin{array}{l}31.95 \\
\pm 1.42\end{array}$ & $\begin{array}{l}38.39 \\
\pm 1.85\end{array}$ & $\begin{array}{l}48.73 \pm \\
2.56\end{array}$ & $\begin{array}{l}65.97 \\
\pm 3.55\end{array}$ & $\begin{array}{l}70.91 \\
\pm 2.91\end{array}$ \\
\hline Ethanolic & $\begin{array}{l}29.65 \\
\pm 1.51\end{array}$ & $\begin{array}{l}44.13 \\
\pm 1.83\end{array}$ & $\begin{array}{l}51.26 \pm \\
2.37\end{array}$ & $\begin{array}{l}64.59 \\
\pm 2.94\end{array}$ & $\begin{array}{l}68.49 \\
\pm 3.15\end{array}$ \\
\hline $\begin{array}{l}\text { Ascorbic } \\
\text { Acid }\end{array}$ & $\begin{array}{l}32.87 \\
\pm 1.35\end{array}$ & $\begin{array}{l}40.68 \\
\pm 1.96 \\
\end{array}$ & $\begin{array}{l}55.41 \pm \\
2.63\end{array}$ & $\begin{array}{l}70.34 \\
\pm 2.88 \\
\end{array}$ & $\begin{array}{l}62.91 \\
\pm 2.85 \\
\end{array}$ \\
\hline
\end{tabular}

Here values are given in \pm mean.

Fig. 1. DPPH free radical scavenging activity of root extracts of Martynia annua in hydro-alcohlic, Acquous and ethanolic fractions.

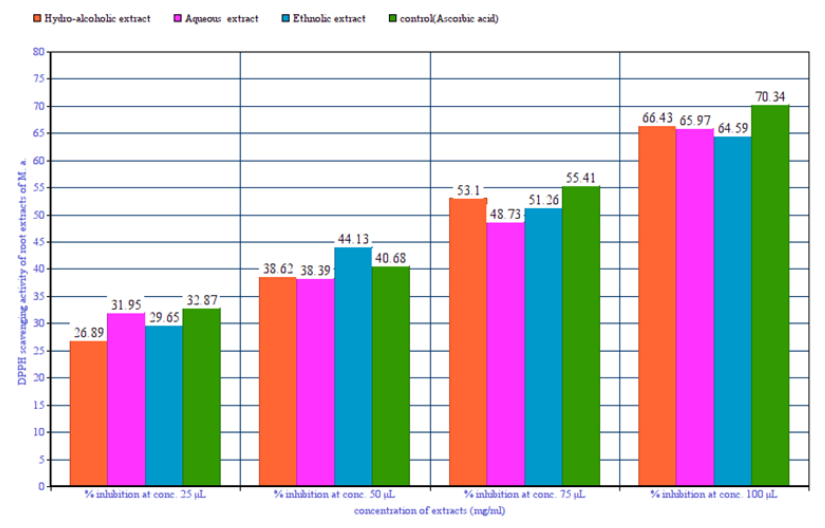

\section{Conclusion}

The present investigation revealed that the root extracts exhibited antioxidant potential which indicated that it can help to improve immune system. Antioxidant activities measured by DPPH free radical scavenging assay. The water extract Martynia annua root showed maximum extent but in ethanol these activities were also significant. The phenolic compounds and flavonoids are responsible of antioxidant activities.

\section{References}

1. http://www.backyardnature.net/q/martynia.htm Sierra Gorda Biosphere Reserve, Querétaro, México September 14, 2007. http://www.backyardnature.net/ q/martynia.htm. (Accessed: 15-Apr-2018).

2. Gupta R and Deogade M, A Critical Review on Martynia annua Linn, vol. 9. 2018.

3. Lodhi, Singhai A.K. Preliminary pharmacological evaluation of Martynia annua leaves. Asian Pacific 
journal of Tropical Biomedicine, 2011; 1(6): 421427.

4. Kenwat, P., Martynia annua UK Journal of pharmaceutical and Biosciences, 2013; 1(1):7- 10.

5. Babu, H.B., Mohana, L.S. Studies on phytochemical and anticonvulsant property of Martynia annua International journal of Phytopharmacology, 2010; 1 (2): 82-86.

6. Ashwani K.D., Bhawan C., Sanjeet K.M. Martynia anuua: A Review on its Ethnobotany and Pharmacological Profile. Journal of Pharmacognosy and Phtochemistry, 2013; 1(6): 135-138.

7. Khare C.P. Encyclopedia of Indian Medicinal Plants. (1956-2007 updated), 2007; 44(10):772- 773.
8. Kirtikar, B. Indian Medicinal Plants, II.in 173038.Kokate KC, 4th ed. Delhi: Vallabh Prakashan,. Practical pharmacognosy, 1994, p. 218.

9. Young I.S. Woodside Antioxedent in health and diseases. J.Clinical Pathology, 2001; 54: 176- 186.

10.Vijay Kumar et al. designing, syntheses, characterization, computational study and biological activities of silver-phenothiazine metal complex. Journal of Molecular Structure 1099 (2015) 135-141. 